\title{
Formulating Interest Subsidy Program to Support the Development of Electricity Generation from Palm Oil Mill Effluent (POME) Biomass: An Indonesian Case Study
}

\author{
Noor Syaifudin ${ }^{1,2^{*}}$, Nurkholis ${ }^{3}$, Rangga Handika ${ }^{4}$, and Roy Hendroko Setyobudi ${ }^{5,6}$ \\ ${ }^{1}$ Fiscal Policy Agency, Ministry of Finance of Republic of Indonesia, J1. Dr.Wahidin Raya No 1, \\ Jakarta, 10710, Indonesia \\ ${ }^{2}$ UWA Business School, Crawley Campus, The University of Western Australia, 35 Stirling \\ Highway, 6009 Perth, Australia \\ ${ }^{3}$ Faculty of Economics, University of Indonesia, Jl. Margonda Raya, Beji, Pondok Cina, Depok, \\ 16424, Indonesia \\ ${ }^{4}$ College of Business Administration, Abu Dhabi University, Abu Dhabi Campus, 59911, Abu Dhabi, \\ Uni Arab Emirates \\ ${ }^{5}$ Waste Laboratory University Muhamadiyah of Malang, Jl. Raya Tlogomas No. 246 Malang, 65114, \\ Indonesia \\ ${ }^{6}$ Indonesian Association of Bioenergy Scientist and Technologist. BPPT Building II, J1. MH. \\ Thamrin. No. 8, Jakarta, 10340, Indonesia
}

\begin{abstract}
This paper analyses financial feasibility and cost-benefit and formulates the relevant subsidy program that is currently implemented by the government. We find that providing interest subsidy is financially feasible only if it serves to substitute the consumption of diesel. The benefits are higher than the costs among three types ( $45 \mathrm{t}, 60 \mathrm{t}$ and $75 \mathrm{t}$ ) of the palm waste generator capacity. The paper also reveals that Credit Program is relevant with the objective, to provide interest subsidy to farmers, but certain adaptations are required.
\end{abstract}

Key words: Cost and benefit analysis, credit program, financial feasibility, interest subsidy, POME

\section{Introduction}

Oil palm, coconuts and sugar cane have higher levels of productivity among other plantation commodities in Indonesia. Besides their main outputs, those commodities produce huge amounts of biomass waste. There are several oil palm biomass wastes among others are midrib, oil palm shell, oilcake and fruit bunches. Coconut provides shell, sawdust, and fibre as dry biomass waste, while sugar canes biomasses are leaves and grout.

*Corresponding author: soib2007@gmail.com 
Among these three commodities, palm oil has developed quite significantly in the last few years.

It is estimated that there are $28.7 \times 10^{6} \mathrm{t}$ of palm oil mill effluent (POME) being produced in Indonesia annually [1]. POME is liquid oil palm waste which still contains dissolved solid materials. Most of these solid materials come from lignocellulosic material producing oil from palm fruit. Generally, POME is processed using a pond system, and potentially produce biogas.

Coconut, oil palm, and sugar cane are mostly spread outside Java Island. Many areas outside of Java Island are not electrified. Therefore, the development of power plants from dry biomass waste is a perfect solution to equip electricity network for people who live outside Java Island. Dry biomass waste has total potential of (2 000 to 3000$) \mathrm{kkal} \mathrm{kg}^{-1}$ of waste. Dry biomass will produce steam which able to generate electricity through a steam turbine generator. Potentials electricity from all biomasses are $49810 \mathrm{MW}$. However, only $3 \%$ (1 $618 \mathrm{MW})$ of the biomasses are currently being utilized. Indeed, $60 \%$ of potential electricity from biomass could be utilized as alternative energy sources as targeted by the government [2].

The Ministry of Environment (MoE) has experience in the provision of renewable energy through the development of biomass power plants from palm oil midrib. Ministry of Energy and Mineral Resources (MEMR) also has experience in developing power plants from POME. Developing a small size $(200 \mathrm{KW})$ palm oil midrib biomass power plant needs funding about IDR $5 \times 10^{9}$. Furthermore, more than IDR $20 \times 10^{9}$ is needed to build one POME power plant. According to the previous experience there are at least three types of power plant from POME: (i) $45 \mathrm{t} \mathrm{h}^{-1}$ can produce $1.5 \mathrm{MW}$ electricity, (ii) $60 \mathrm{t} \mathrm{h}^{-1}$ for $2 \mathrm{MW}$ electricity and (iii) $75 \mathrm{t} \mathrm{h}^{-1}$ for $3.5 \mathrm{MW}$ electricity. There two main objectives of developing power plants from oil palm midrib and POME. The objectives are: (i) to produce electricity (either to be privately consumed or to be sold for household lighting) and (ii) to reduce/substitute diesel fuel consumption.

\section{Development of electric power plant biogas from palm industry waste}

Various studies have been conducted to address issue on energy subsidy. For instance, Moiseyev et al. [3] projected impact of subsidies and carbon pricing on the use of wood biomass for energy in the UK. Another study by Sun et al. [4] investigates subsidies on household biogas use in China, while a study by Gharibnavaz and Waschik [5] investigate the food and energy subsidy reform in Iran. Nauleau et al. [6] argue that subsidy should be differentiated to achieve the social optimum. Chen et al. [7] propose a sewage charge to encourage producers' emphasis on dung disposal. Their implication will lead to an increase on the effect of subsidy policy. Another paper by Zhao et al. [8] finds that renewable energy subsidy generates environmental benefits. Their paper also notes that energy security triggers technology innovation and economic growth. Thus, they conclude that the subsidy policy generates positive impacts. However, Shen and Luo [9] document negative effect of providing subsidy on renewable energy at a certain threshold in China. Therefore, subsidy policy has both positive and negative impacts. In order to generate positive impacts, a subsidy policy should differentiate the tariff level, applicable to renewable energy and on households level, and able to support the environmental benefit.

Instead of merely discussing the impacts and aspects of the subsidy, scholars also address the prerequisite and structural reform of subsidy on energy to meet the optimum level of the policy. A study by Johnston et al. [10] propose a stable, secure and fully functional energy system in the EU due to the important role of energy sector towards economic growth and job creation. Du and Mickiewicz [11] argue that the energy subsidy 
will be enjoyed more by private and big companies, while the public, small and young firms will enjoy less. Castiblanco et al. [12] recommend that the comprehensive approaches are vital in order to optimize the subsidy on renewable energy. They suggest that the government should ensure that the renewable energy investment is profitable enough. They find that producers of palm oil will gain from the renewable energy investment most in the short term. However, the biodiesel firm will gain more from the renewable energy investment in the long run.

There are two initial conditions before estimating the financial feasibility of the investment. The conditions are: (i) Gaining revenue from selling the electric as the result of the development of the biogas reactor, (ii) Reducing cost by substituting or saving diesel (non-subsidized diesel). The results show that development of biogas electricity generator from POME will be feasible if it serves to substitute diesel (see Table 1 to Table 4 in appendix). On the other hand, the development of POME reactor to produce electricity and sell it to households is not feasible. It is not feasible because electricity production is relatively small and the electricity price is relatively low (compared to the cost). The cost and benefit analysis indicates that the scores are greater than 1. This means that all investments are economically feasible (see Table 5 in appendix).

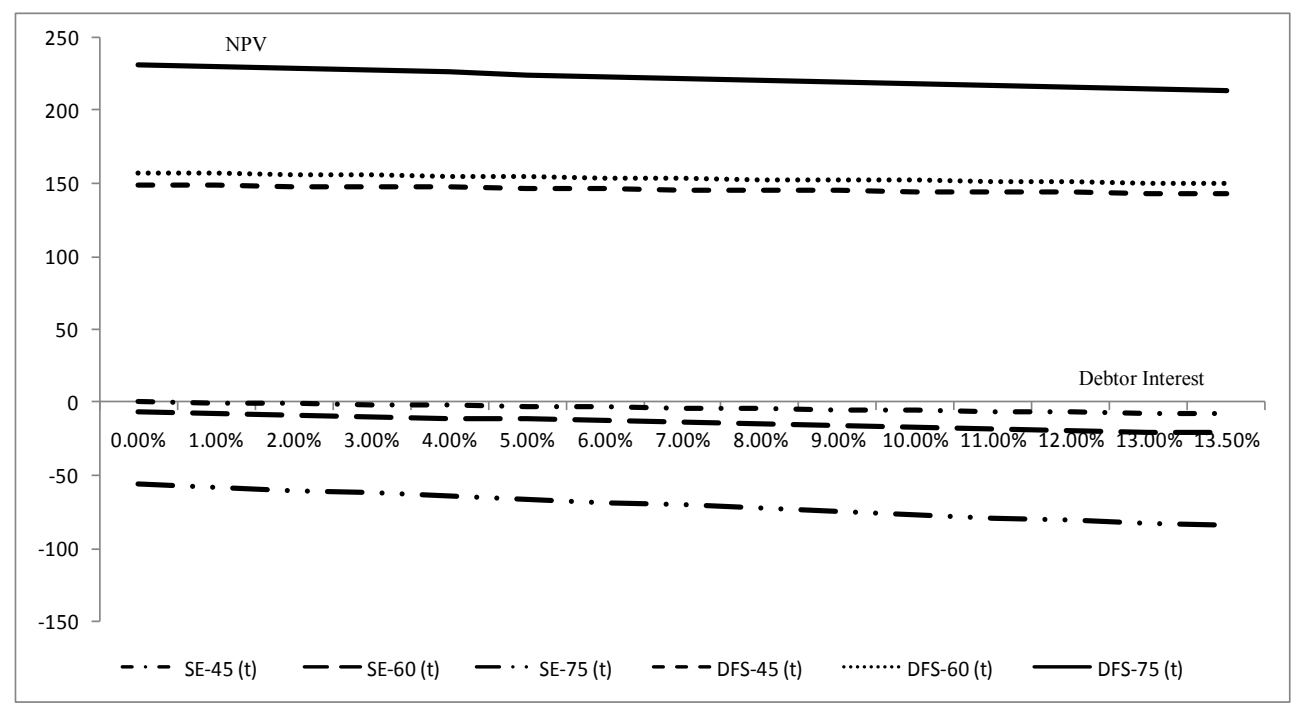

Fig. 1. Debtor interest sensitivity on the net present value (NPV). 


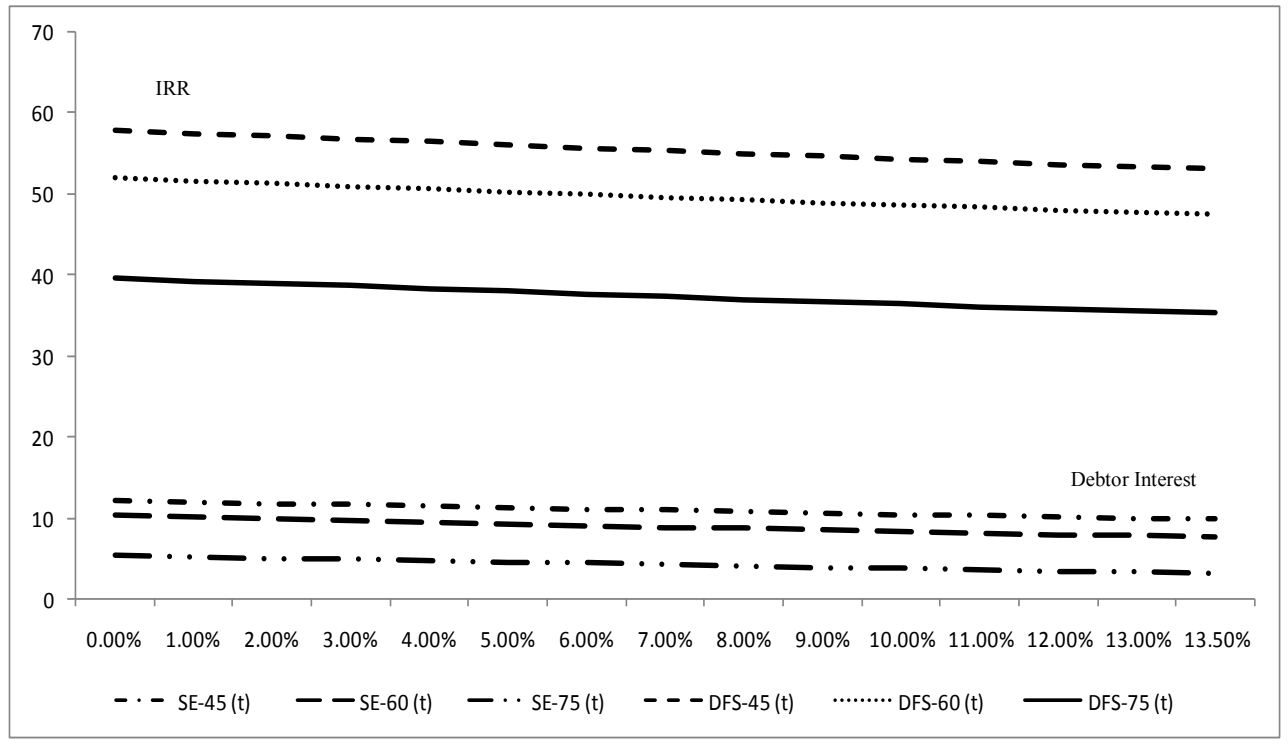

Fig. 2. Debtor interest sensitivity on the internal rate of return (IRR).

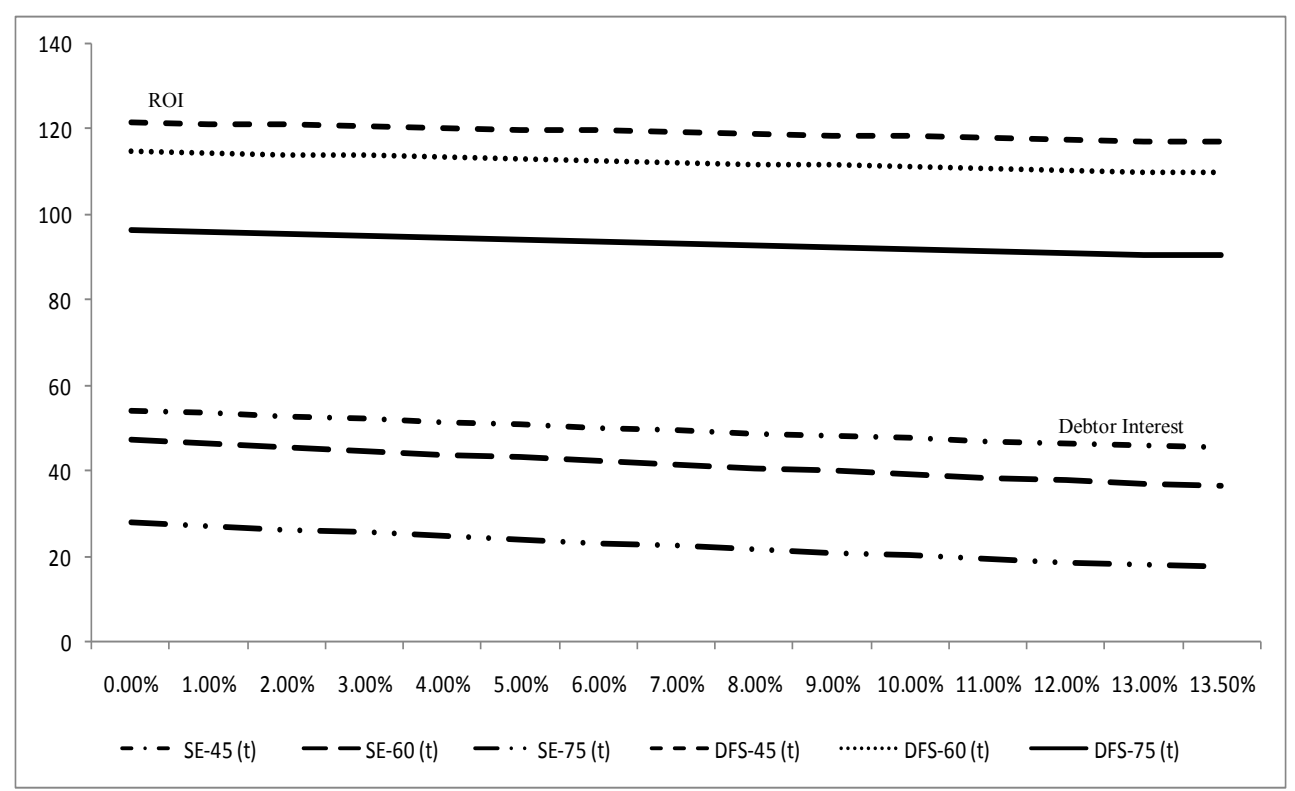

Fig. 3. Debtor interest sensitivity on the return on investment (ROI). 


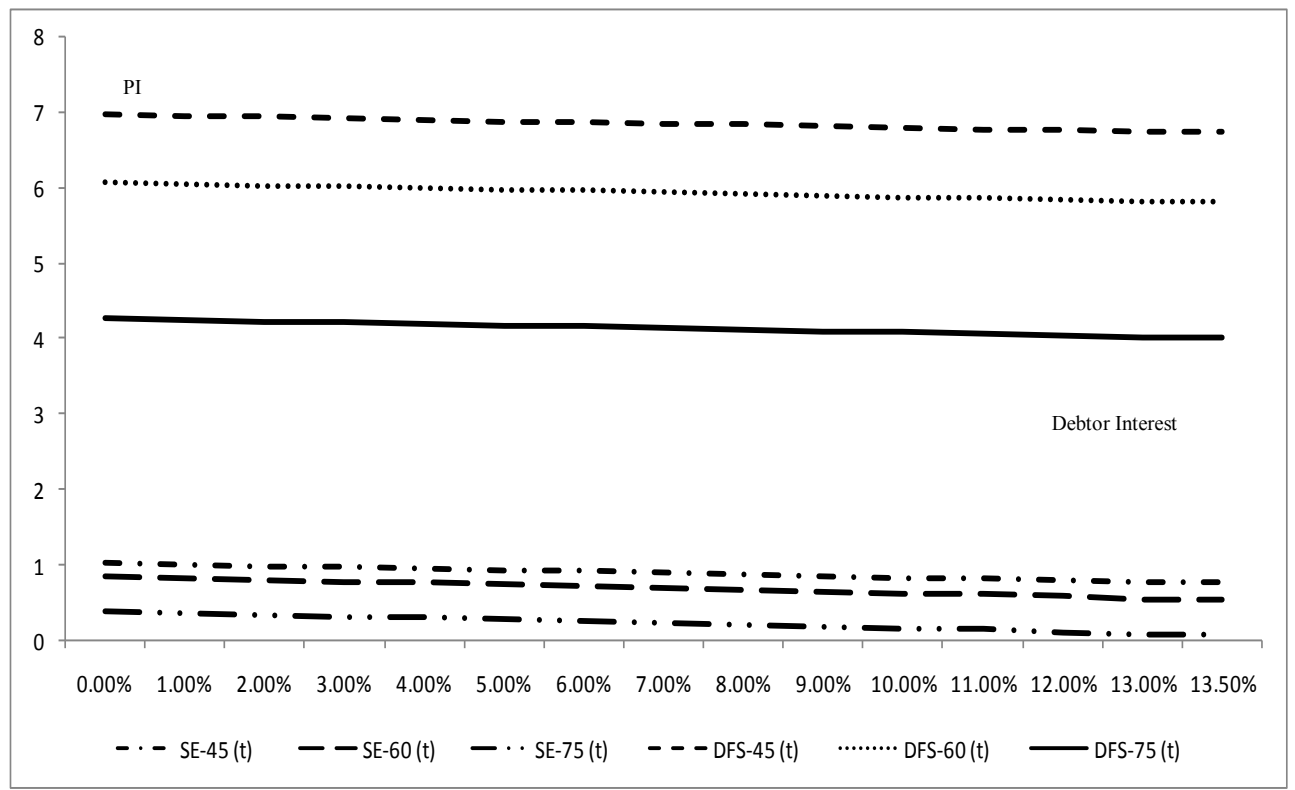

Fig. 4. Debtor interest sensitivity on the profitability index (PI).

Figure 1 to Figure 4 show the sensitivity of the various of debtor interest rate with respect to the value of NPV, IRR, ROI and PI for various capacities of biomass power plant from POME. It is revealed that the higher the debtor interest rate, the lower the value of NPV, IRR, ROI and PI. The analysis presents that NPV, IRR, ROI and RI is much higher for diesel fuel substitution (DFS) compared to the selling electricity (SE), because the price of diesel oil is high and the pollution resulted is also high.

\section{Proposed mechanism for financing WTE investment through a credit program}

According to the Law No. 23/1999 about Central Bank of Indonesia [13] - as later amended to Law No. 3/2004 [14] - the Central Bank is not allowed to provide credit to support the government priority sectors. Therefore, the responsibility is on the government policy. The policy is Credit Programs that involves financing to support the development of priority sectors. The fund comes from the bank that lends to the borrower with a low interest rate. The difference between the actual interest rate and market interest rates will be paid by the government via interest subsidy.

Many loan programs have been launched by government such as Credit for Food and Energy Security (Kredit Ketahanan Pangan dan Energi/KKP-E), Cattle Breeding Credit (Kredit Usaha Pembibitan Sapi/KUPS); and Credit for Bio Energy Program and Plantation Revitalization (Kredit Pengembangan Energi Nabati dan Revitalisasi Perkebunan/KPEN$\mathrm{RP}$ ). There are also loan programs based on a guarantee scheme. One of the programs is People's Business Credit (Kredit Usaha Rakyat/KUR). The KUR provides loan for Small and Medium Enterprises (SMEs) and Cooperatives, particularly for feasible but not bankable entities.

The objectives of the WtE investment financing program are: (i) Supporting the government commitment in reducing greenhouse gas emission, (ii) Supporting investment projects in WTE and giving economic benefits to the investors, (iii) Increasing the total 
funds available for WTE investments, and (iv) Giving financial access to the SMEs and Cooperatives to WTE.

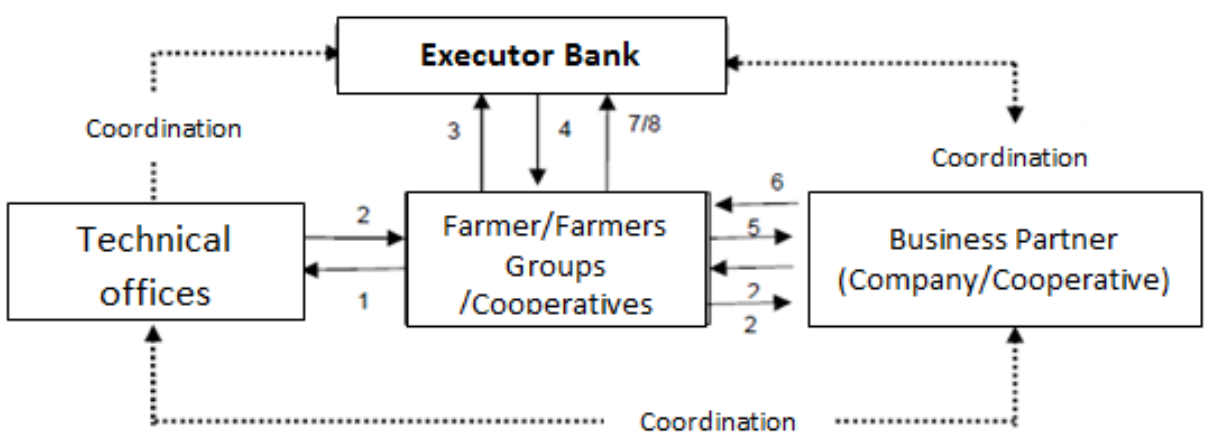

Fig. 5. Procedures of credit program for farmer/farmers group/cooperatives with business partner/s.

Figure 5 describes the channelling scheme of interest subsidy from the banks to debtor/s. The scheme can be elaborated as follows: (i) Individual and group of farmers as the debtor/s prepare loan and business plan assisted by technical assistant from agriculture agency; (ii) The technical assistant endorse the loan and business plan; (iii) The debtor/s submit the plan to the executor bank; (iv) Debtor/s who have partnership with State Owned Enterprise (SOE), Cooperative and private farming companies, can appoint the partner as a loan guarantor; (v) If the contract requests, parts of loan can be overlanded to the guarantor. For instance, cooperatives can act as guarantor of their members; (vi) The partner can guarantee the marketing of products of farmers/farmer groups/cooperatives and assist the debtor/s to repay their loans as well as coordinate with executor bank; and (vii) Debtor/s pay back the credit to the bank.

\section{Conclusion}

The development of energy generation from POME can benefit society and the government. The role of the government is essential because of the enormous potential electricity and the huge funding. One of the government roles is providing loan interest subsidy. This study finds that the provision of interest subsidies is financially viable if it serves to substitute the use of diesel fuel. The costs and benefits analysis reveals that the interest subsidy generates positive value to the economy. Finally, a mechanism to assist the debtor in accessing the funding is required to implement the interest subsidy to farmers program successfully. The more discussions about the mechanism with the relevant stakeholders are expected to be more beneficial and may produce optimum results.

\section{References}

1. Irvan, B. Trisakti, M. Vincent, Y. Tandean. Jurnal Teknik Kimia USU, 1,2:27-30(2012). [in Bahasa Indonesia]. https://jurnal.usu.ac.id/index.php/jtk/article/view/121

2. Sarono, E.G. Sa'id, O. Suparno, Suprihatin, U. Hasanudin. Jurnal Teknologi Industri Pertanian, 24,1:11-19(2014). [in Bahasa Indonesia]. http://journal.ipb.ac.id/index.php/jurnaltin/article/view/8083

3. A. Moiseyev, B. Solberg, A.M.I. Kallio. Energy. 76:161-167(2014). https://www.sciencedirect.com/science/article/pii/S0360544214006173 
4. D. Sun, J. Bai, H. Qiu, Y. Cai. Energy Policy, 73:748-756(2014).

https://www.sciencedirect.com/science/article/pii/S0301421514003814

5. M.H. Gharibnavaz, R. Waschik. Journal of Policy Modeling, 37,5:726-741(2015). https://www.sciencedirect.com/science/article/pii/S0161893815000794

6. M.L. Nauleau, L.G. Giraudet, P. Quirion. Energy Economics, 52,1:S53-S62(2015). https://www.sciencedirect.com/science/article/pii/S0140988315002479

7. Y. Chen, S.J. Wang, C.C. Tsai, C.J. Zhang. Journal of Cleaner Production, 112,4:2529-2535(2015).

https://www.sciencedirect.com/science/article/pii/S0959652615013189

8. H. Zhao, S. Guo, L.W. Fu. Renewable and Sustainable Energy Reviews, 37:538549(2014). https://www.sciencedirect.com/science/article/pii/S1364032114003864

9. J. Shen, C. Luo. Renewable and Sustainable Energy Reviews, 41:1478-1488(2015). https://www.sciencedirect.com/science/article/pii/S1364032114007801

10. A. Johnston, R.J. Heffron, D. McCauley. Energy Research and Social Science, 3:14(2014). https://www.sciencedirect.com/science/article/pii/S2214629614000632

11. J. Du, T. Mickiewicz. Journal of Business Venturing, 31,1:22-38(2015). https://www.sciencedirect.com/science/article/abs/pii/S0883902615000622

12. C. Castiblanco, A. Moreno, A. Etter. Energy Economics, 49:676-686(2015). https://www.sciencedirect.com/science/article/pii/S0140988315000997

13. RI (Republic of Indonesia). Undang-undang no. 23 tahun 1999 tentang Bank Indonesia. [Law no. 23/1999 on Central Bank]. Jakarta (1999). [in Bahasa Indonesia]. https://www.bi.go.id/id/tentang-bi/uu-bi/Documents/uu\%20bi\%2023\%20th\%2099.pdf

14. RI (Republic of Indonesia). Undang-undang no. 3 tahun 2004 tentang Perubahan Undang-undang no. 23 tahun 1999 tentang Bank Indonesia [Law no. 3/2004 on Amendment Law no. 23/1999 on Central Bank]. Jakarta (2004). [in Bahasa Indonesia]. https://www.bi.go.id/id/tentang-bi/uu-bi/Documents/uu bi_no0304.pdf

\section{APPENDIX}

Table 1. NPV estimation.

\begin{tabular}{|c|c|c|c|c|c|c|}
\hline \multirow{2}{*}{$\begin{array}{c}\text { Debtor } \\
\text { Interest }\end{array}$} & \multicolumn{3}{|c|}{$\begin{array}{c}\text { Selling Electricity NPV } \\
(\mathbf{1 0} \text { IDR) }\end{array}$} & \multicolumn{3}{c|}{$\begin{array}{c}\text { Diesel Fuel Substitution NPV } \\
(\mathbf{1 0} \text { IDR) }\end{array}$} \\
\cline { 2 - 7 } & $\mathbf{4 5}(\mathbf{t})$ & $\mathbf{6 0}(\mathbf{t})$ & $\mathbf{7 5}(\mathbf{t})$ & $\mathbf{4 5}(\mathbf{t})$ & $\mathbf{6 0}(\mathbf{t})$ & $\mathbf{7 5}(\mathbf{t})$ \\
\hline $0.0 \%$ & $(0.94)$ & $(6.60)$ & $(55.91)$ & 148.84 & 157.44 & 231.42 \\
\hline $1.0 \%$ & $(0.26)$ & $(7.61)$ & $(58.05)$ & 148.39 & 156.88 & 230.13 \\
\hline $2.0 \%$ & $(0.41)$ & $(8.62)$ & $(60.20)$ & 147.94 & 156.31 & 228.84 \\
\hline $3.0 \%$ & $(1.08)$ & $(9.63)$ & $(62.34)$ & 147.48 & 155.74 & 227.55 \\
\hline $4.0 \%$ & $(1.76)$ & $(10.64)$ & $(64.49)$ & 147.03 & 155.18 & 226.25 \\
\hline $5.0 \%$ & $(2.43)$ & $(11.65)$ & $(66.63)$ & 146.58 & 154.61 & 224.96 \\
\hline $6.0 \%$ & $(3.11)$ & $(12.66)$ & $(68.78)$ & 146.12 & 154.05 & 223.67 \\
\hline $7.0 \%$ & $(3.78)$ & $(13.67)$ & $(70.92)$ & 145.67 & 153.48 & 222.38 \\
\hline $8.0 \%$ & $(4.46)$ & $(14.68)$ & $(73.06)$ & 145.22 & 152.92 & 221.09 \\
\hline $9.0 \%$ & $(5.13)$ & $(15.69)$ & $(75.21)$ & 144.76 & 152.35 & 219.80 \\
\hline $10.0 \%$ & $(5.80)$ & $(16.70)$ & $(77.35)$ & 144.31 & 151.78 & 218.50 \\
\hline $11.0 \%$ & $(6.48)$ & $(17.71)$ & $(79.50)$ & 143.85 & 151.22 & 217.21 \\
\hline $12.0 \%$ & $(7.15)$ & $(18.72)$ & $(81.64)$ & 143.40 & 150.65 & 215.92 \\
\hline $13.0 \%$ & $(7.83)$ & $(19.73)$ & $(83.79)$ & 142.95 & 150.09 & 214.63 \\
\hline $13.5 \%$ & $(8.16)$ & $(20.23)$ & $(84.86)$ & 142.72 & 149.80 & 213.98 \\
\hline
\end{tabular}


Table 2. IRR estimation.

\begin{tabular}{|c|c|c|c|c|c|c|}
\hline \multirow{2}{*}{$\begin{array}{c}\text { Debtor } \\
\text { Interest }\end{array}$} & \multicolumn{3}{|c|}{ Selling Electricity IRR } & \multicolumn{3}{c|}{ Diesel Fuel Substitution IRR } \\
\cline { 2 - 7 } & $\mathbf{4 5}(\mathbf{t})$ & $\mathbf{6 0}(\mathbf{t})$ & $\mathbf{7 5}(\mathbf{t})$ & $\mathbf{4 5}(\mathbf{t})$ & $\mathbf{6 0}(\mathbf{t})$ & $\mathbf{7 5}(\mathbf{t})$ \\
\hline $0.0 \%$ & 12.26 & 10.44 & 5.55 & 58.02 & 52.15 & 39.60 \\
\hline $1.0 \%$ & 12.07 & 10.22 & 5.37 & 57.64 & 51.79 & 39.27 \\
\hline $2.0 \%$ & 11.89 & 10.00 & 5.19 & 57.27 & 51.43 & 38.95 \\
\hline $3.0 \%$ & 11.70 & 9.79 & 5.01 & 56.90 & 51.07 & 38.64 \\
\hline $4.0 \%$ & 11.52 & 9.57 & 4.84 & 56.53 & 50.72 & 38.32 \\
\hline $5.0 \%$ & 11.34 & 9.37 & 4.67 & 56.16 & 50.36 & 38.01 \\
\hline $6.0 \%$ & 11.17 & 9.16 & 4.50 & 55.80 & 50.02 & 37.71 \\
\hline $7.0 \%$ & 11.00 & 8.97 & 4.33 & 55.44 & 49.67 & 37.40 \\
\hline $8.0 \%$ & 10.83 & 8.77 & 4.16 & 55.08 & 49.33 & 37.10 \\
\hline $9.0 \%$ & 10.66 & 8.58 & 3.99 & 54.72 & 48.99 & 36.80 \\
\hline $10.0 \%$ & 10.49 & 8.39 & 3.84 & 54.37 & 48.65 & 36.51 \\
\hline $11.0 \%$ & 10.33 & 8.20 & 3.68 & 54.02 & 48.32 & 36.21 \\
\hline $12.0 \%$ & 10.17 & 8.02 & 3.52 & 53.67 & 47.99 & 35.93 \\
\hline $13.0 \%$ & 10.01 & 7.88 & 3.37 & 53.33 & 47.66 & 35.64 \\
\hline $13.5 \%$ & 9.93 & 7.75 & 3.21 & 53.16 & 47.49 & 35.50 \\
\hline
\end{tabular}

Table 3. ROI estimation

\begin{tabular}{|c|c|c|c|c|c|c|}
\hline \multirow{2}{*}{$\begin{array}{c}\text { Debtor } \\
\text { Interest }\end{array}$} & \multicolumn{3}{|c|}{ Selling Electricity ROI } & \multicolumn{3}{c|}{ Diesel Fuel Substitution ROI } \\
\cline { 2 - 7 } & $\mathbf{4 5}(\mathbf{t})$ & $\mathbf{6 0}(\mathbf{t})$ & $\mathbf{7 5}(\mathbf{t})$ & $\mathbf{4 5}(\mathbf{t})$ & $\mathbf{6 0}(\mathbf{t})$ & $\mathbf{7 5}(\mathbf{t})$ \\
\hline $0.0 \%$ & 54.32 & 47.45 & 28.12 & 121.62 & 115.01 & 96.47 \\
\hline $1.0 \%$ & 53.64 & 46.58 & 27.27 & 121.27 & 114.63 & 96.02 \\
\hline $2.0 \%$ & 52.97 & 45.73 & 26.43 & 120.92 & 114.25 & 95.58 \\
\hline $3.0 \%$ & 52.31 & 44.89 & 25.60 & 120.57 & 113.87 & 95.14 \\
\hline $4.0 \%$ & 51.65 & 44.06 & 24.78 & 120.22 & 113.50 & 94.70 \\
\hline $5.0 \%$ & 51.00 & 43.24 & 23.97 & 119.87 & 113.12 & 94.26 \\
\hline $6.0 \%$ & 50.35 & 42.43 & 23.17 & 119.52 & 112.75 & 93.83 \\
\hline $7.0 \%$ & 49.71 & 41.62 & 22.38 & 119.18 & 112.38 & 93.40 \\
\hline $8.0 \%$ & 49.07 & 40.83 & 21.61 & 118.83 & 112.01 & 92.96 \\
\hline $9.0 \%$ & 48.44 & 40.04 & 20.84 & 118.49 & 111.64 & 92.53 \\
\hline $10.0 \%$ & 47.82 & 39.26 & 20.08 & 118.14 & 111.27 & 92.11 \\
\hline $11.0 \%$ & 47.20 & 38.50 & 19.33 & 117.80 & 110.90 & 91.68 \\
\hline $12.0 \%$ & 46.58 & 37.74 & 18.59 & 117.46 & 110.54 & 91.26 \\
\hline $13.0 \%$ & 45.97 & 36.98 & 17.86 & 117.12 & 110.17 & 90.84 \\
\hline $13.5 \%$ & 45.67 & 36.61 & 17.50 & 116.95 & 109.99 & 90.63 \\
\hline
\end{tabular}


Table 4. PI estimation.

\begin{tabular}{|c|c|c|c|c|c|c|}
\hline \multirow{2}{*}{ Debtor Interest } & \multicolumn{3}{|c|}{ Electricity Selling PI } & \multicolumn{3}{c|}{ Diesel Fuel Substitution PI } \\
\cline { 2 - 7 } & $\mathbf{4 5}(\mathbf{t})$ & $\mathbf{6 0}(\mathbf{t})$ & $\mathbf{7 5}(\mathbf{t})$ & $\mathbf{4 5}(\mathbf{t})$ & $\mathbf{6 0}(\mathbf{t})$ & $\mathbf{7 5}(\mathbf{t})$ \\
\hline $0.0 \%$ & 1.03 & 0.85 & 0.39 & 6.99 & 6.08 & 4.27 \\
\hline $1.0 \%$ & 1.01 & 0.83 & 0.37 & 6.97 & 6.06 & 4.25 \\
\hline $2.0 \%$ & 0.99 & 0.81 & 0.35 & 6.95 & 6.04 & 4.23 \\
\hline $3.0 \%$ & 0.97 & 0.78 & 0.32 & 6.93 & 6.02 & 4.21 \\
\hline $4.0 \%$ & 0.95 & 0.76 & 0.30 & 6.91 & 6.00 & 4.20 \\
\hline $5.0 \%$ & 0.93 & 0.74 & 0.28 & 6.89 & 5.98 & 4.18 \\
\hline $6.0 \%$ & 0.92 & 0.71 & 0.25 & 6.88 & 5.97 & 4.16 \\
\hline $7.0 \%$ & 0.90 & 0.69 & 0.23 & 6.86 & 5.95 & 4.14 \\
\hline $8.0 \%$ & 0.88 & 0.67 & 0.21 & 6.84 & 5.93 & 4.12 \\
\hline $9.0 \%$ & 0.86 & 0.65 & 0.18 & 6.82 & 5.91 & 4.10 \\
\hline $10.0 \%$ & 0.84 & 0.62 & 0.16 & 6.80 & 5.89 & 4.09 \\
\hline $11.0 \%$ & 0.84 & 0.62 & 0.16 & 6.78 & 5.88 & 4.07 \\
\hline $12.0 \%$ & 0.81 & 0.58 & 0.11 & 6.77 & 5.86 & 4.05 \\
\hline $13.0 \%$ & 0.79 & 0.55 & 0.09 & 6.75 & 5.84 & 4.03 \\
\hline $13.5 \%$ & 0.78 & 0.54 & 0.08 & 6.74 & 5.83 & 4.02 \\
\hline
\end{tabular}

Table 5. Cost and benefit analysis of development of biogas reactor from POME (the benefit assumptions are for $20 \mathrm{yr}$ with loan maturities of $5 \mathrm{yr}$ ).

\begin{tabular}{|c|c|c|c|c|}
\hline No. & Indicators & $\begin{array}{c}45 \mathrm{t} \\
\text { Palm Oil Fresh } \\
\text { Fruit Bunches }\end{array}$ & $\begin{array}{c}\text { 60 t } \\
\text { Palm Oil Fresh } \\
\text { Fruit Bunches }\end{array}$ & $\begin{array}{c}\text { 75 t } \\
\text { Palm Oil Fresh } \\
\text { Fruit Bunches }\end{array}$ \\
\hline 1. & $\begin{array}{c}\text { Initial cost-selling price } \\
\text { of electricty (IDR) }\end{array}$ & 42396678573 & 44196687578 & 92220853048 \\
\hline 2. & $\begin{array}{l}\text { Initial cost- saving from } \\
\text { diesel fuel (IDR) }\end{array}$ & 29581284210 & 31018593375 & 70806449968 \\
\hline 3. & Loan period (Year) & 5 & 5 & 5 \\
\hline 4. & Interest Rate by Bank & $13.5 \%$ & $13.5 \%$ & $13.5 \%$ \\
\hline \multirow[t]{15}{*}{5.} & Simulation & & & \\
\hline & $\begin{array}{c}\text { Assumption for } \\
\text { electricity selling price }\end{array}$ & & & \\
\hline & Cost (C)(IDR) & 137122560225 & 146746347401 & 293578389012 \\
\hline & Benefit (B) (IDR) & 236398939765 & 254359349049 & 434552531685 \\
\hline & Net benefit (IDR) & 99276379540 & 107613001648 & 140974142673 \\
\hline & B per C Ratio (BCR) & 1.72 & 1.73 & 1.48 \\
\hline & Feasibility (if BCR > 1) & Feasible & Feasible & Feasible \\
\hline & $\begin{array}{c}\text { CO2 Emission } \\
\text { Reduction (Ton) }\end{array}$ & 826818.86 & 890604.30 & 1447231.98 \\
\hline & $\begin{array}{l}\text { Assumption from } \\
\text { saving diesel fuel }\end{array}$ & & & \\
\hline & Cost (C)(IDR) & 186035035800 & 192966778018 & 370321553481 \\
\hline & Benefit (B) (IDR) & 507344753694 & 526585561403 & 849405525155 \\
\hline & Net benefit (IDR) & 321309717894 & 333618783385 & 479083971674 \\
\hline & B per C Ratio (BCR) & 2.73 & 2.73 & 2.29 \\
\hline & Feasibility (if BCR > 1) & Feasible & Feasible & Feasible \\
\hline & $\begin{array}{c}\text { CO2 Emission } \\
\text { Reduction (Ton) }\end{array}$ & 826818.86 & 890604.30 & 1447231.98 \\
\hline
\end{tabular}

